\title{
Remaking an 'Old Tradition's Magic': The Irish Strain in Early Queensland Writing
}

\author{
Belinda McKay and Patrick Buckridge \\ b.mckay@griffith.edu.au, p.buckridge@griffith.edu.au
}

The themes of cultural dislocation and the struggle to feel 'at home' in a new land figure prominently in Australian literature, and considerable critical attention has been devoted to the distinctive articulations of these preoccupations by wellknown writers of Irish birth or descent, such as Victor Daley, Bernard O'Dowd and John O'Brien. Queensland's Irish writers, however, have been largely forgotten or overlooked - both individually and as a group.

Being a poet in Ireland in the late nineteenth century meant more than being a poet in Queensland, and the Irish who came to Queensland with poetic talents or aspirations had to come to terms with that difference, one way or another. This article spans the period from Separation in 1859 to the middle of the twentieth century. It begins by looking at the role of those who were born in Ireland and migrated to Queensland, and who became writers either before they left or after they arrived. We begin with first-generation immigrants, because the processes of translation and adjustment might be expected to be experienced more immediately in the lives of people who had lived in both Ireland and Queensland, and therefore to be more visible in their writing, than in the poetry of the second and later generations of Irish in Queensland. It is therefore of some interest to look for patterns of adjustment in the work of those writers who literally brought their Irishness with them to Queensland. However, the power of old traditions, and even the sense of dislocation in the new country, can sometimes bulk larger for the descendants than for the immigrants themselves. For this reason, we also consider the Irish strain in the work of some Queensland-born writers of Irish descent.

Poets, both male and female, could command a kind of public recognition and respect in Ireland in the later nineteenth century that the poets of less lyrical national cultures could only envy. Their status derived partly from their ongoing contributions to the nationalist struggle - for example, through newspapers like The Nation - and partly from the centuries-long traditions of bardic prophecy and satire, and the more recent history of Gaelic love poetry. That was the myth - the real status of poets was doubtless less elevated - but in any case, cultural myths are probably more important than social realities in giving poets a feeling of purpose and belonging. 
The literary arts — especially poetry — flourished in Queensland from the middle of the nineteenth century. Poets like James Brunton Stephens and George Essex Evans (neither of them Irish) had national reputations in the 1870s; Rosa Praed (who was of Irish descent) achieved considerable fame as a novelist in England in the late nineteenth and early twentieth centuries; and there were a number of lesser figures as well. What part did Irish-born writers - those carriers of the flame of Goldsmith and Moore, Mangan and Davis - play in this flourishing? The answer seems to be that, despite the fact that Queensland was the Australian colony that attracted the highest rate of migration from Ireland in the late nineteenth and early twentieth centuries, Irish immigrants were significantly under-represented in literary culture. J. H. Hornibrook's 1953 Bibliography of Queensland verse, published with biographical notes and based on the collections of the John Oxley Library, lists fewer than twenty poets of both sexes born in Ireland. ${ }^{1}$ Although our research has uncovered a few more Irish poets active in early Queensland, and a few novelists, short story writers and essayists, the number of Irish writers appears to be disproportionately low. Indeed, the ongoing Irish strain in Queensland literature (such as it is) is attributable largely to women writers - another under-represented group - and especially to women who were born in Queensland of Irish descent.

The Irish tradition in Queensland writing was initiated with the arrival of two established women poets in the early 1860 s, shortly after the separation of the colony from New South Wales in 1859. Mrs Hope Connolly was born Olivia Mary Knight at Castlebar, County Mayo in the same year that Mary Eva O'Doherty was born Mary Anne Kelly in Headford, County Galway. Before migrating to Australia, both women had been well-known contributors to the Young Ireland periodical The Nation, writing under the pen names of 'Thomasine' and 'Eva' respectively. Both women came to Queensland at the instigation of Bishop Quinn - Connolly (then Olivia Knight) in 1860 and O'Doherty with her husband Dr Kevin Izod O'Doherty in 1862. Connolly arrived directly from Ireland on the Erin-go-bragh, but the O'Dohertys settled briefly in Sydney.

The poems that 'Thomasine' and 'Eva' wrote for The Nation were part of a nationalist literary project inflected by gender: using the voice of the patriot mother or lover, they elaborated a female version of prophetic nationalism. In 'My voice of song', for instance, O'Doherty represents her poetry as inspired by and dedicated to Ireland:

My voice of song is given to thee, 'Land of the murmuring streams!'

Thou art the worshipped of my heart, The light that gilds my dreams!

Thy name - the flower upon my path,

The star within my sky;

And as for thee I gladly live, So I for thee would die! ${ }^{2}$

Commentators such as Kellow have remarked on the similarities of Irishness, style and preoccupations between the two women poets. ${ }^{3}$ Their politics were not identical, however. In 1852, 'Eva' wrote a despairing 'Lament for Ireland' that 'Thomasine' felt was more likely to discourage than fortify the nationalist struggle. She therefore penned 'A remonstrance: to "Eva"' in response; in it, she emphasised 
the particular responsibility of women poets in summoning their 'Sisters' to support the rebel cause. ${ }^{4}$ Eva, however, had good reason to feel despondent. Her Young Irelander fiancé, Kevin Izod O'Doherty, had been arrested in 1848 and transported to Van Diemen's Land in 1849; the couple was not reunited until 1855, when O'Doherty was released and returned incognito to Ireland.

For both women, the move to the new colony was unsettling, as it deprived them of a public literary role in a political movement. 'Thomasine', or Mrs Hope Connolly as she was known in Queensland, was employed as a teacher in various parts of the colony; she wrote only occasionally after migrating to Queensland, and then almost exclusively about Ireland. In 'Mater Dolorosa' (written in 1861), for instance, she hails the diaspora as Ireland's salvation, promising England that Ireland's 'banished seed' will become 'dragon's teeth' and destroy her imperial power. ${ }^{5}$ But by 1865 , Connolly's faith in the diaspora as a source of renewal was waning. Colonials, she observes in 'The Contrast: II', are interested not in griefstricken Ireland but in the new land, 'all free and bright and gay'. The struggle must be resolved back in the homeland: 'Sons of my native land!' she urges, 'the answer rests with you!'6

Unlike Connolly, O'Doherty wrote a few poems that engage with the conditions of life in Queensland, ${ }^{7}$ but she confessed to being afflicted by the difficulty of finding a voice in a land that held 'no old tradition's magic' itual associations. The ironies generated by transferring prophetic nationalism in the Irish mould to the Australian context are epitomised by her poem 'Queensland', which depicts the new colony as 'a lovely land ... by shadows dark untainted', but at the same time 'cold and soulless' because it lacks, as yet, the 'touch informing' of the poet.

To wake thy voiceless, silent air

To soft, melodious numbers;

To raise thy lifeless form, so fair,

From those deep, spell-bound slumbers,

Oh, whose shall be the potent hand

To give that touch informing,

And make thee rise, O southern land,

To life and poesy warming??

According to Ross and Heather Patrick, Eva O'Doherty suffered from nostalgia for Ireland and was 'never really content in Queensland'. ${ }^{10}$ Deprived of their roles in the Irish literary nationalist movement, both Connolly and O'Doherty wrote relatively little in Queensland, and found difficulty in transferring their passionate commitment to Irish nationalism to a colonial environment with barely a fledgling literary infrastructure.

If even 'Thomasine' and 'Eva' of The Nation found it hard to maintain their nationalist voices, it is hardly surprising that Irish nationalism is at best a sporadic theme in the work of later Irish women writers who came to Queensland. Mary Egan Mulry was born at Morganstown, County Roscommon in 1863, and arrived in Queensland in 1886 at the age of twenty-three. Her poem, 'My dream', typifies the tendency of Irish women writers to represent the idea of a united, free Ireland as a fanciful and unobtainable vision rather than as a cause to which the Australian Irish could commit themselves actively: 'Thus I saw Ireland, a nation free, 


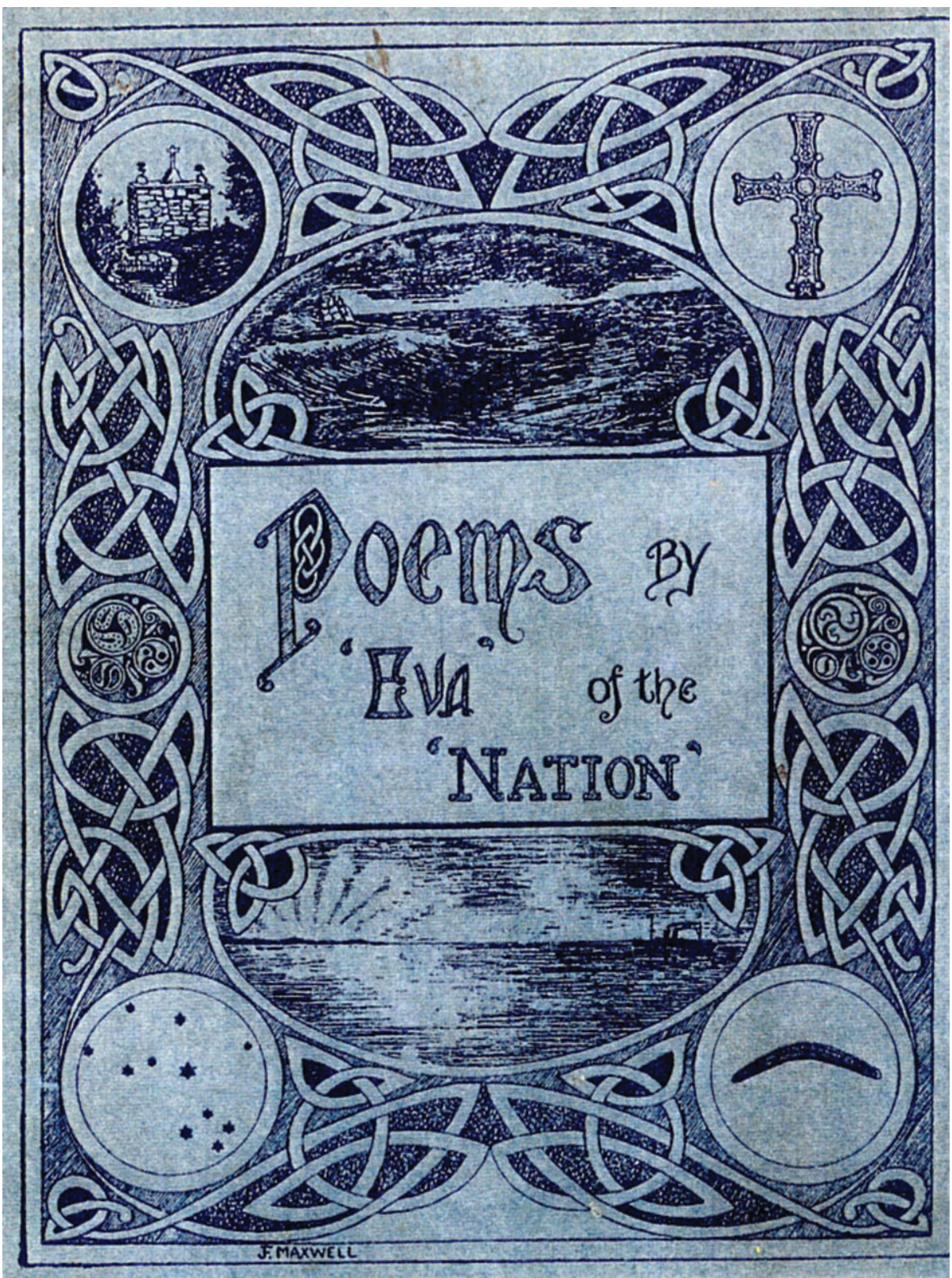

(Colour online) The cover of Mary Eva O'Doherty's Poems by 'Eva' of the 'Nation' (Dublin: M.H. Gill, 1909) encapsulates in its imagery her desire to remake the 'old tradition's magic' in a new land.

prosperous and grand, / And I thought I wandered thro' the fields as I used to when a child ...' 11

The earliest of the Irish male writers active in Queensland is a Mayne - though no immediate relation to the better known Patrick Mayne, as far as we know. Robert West Mayne was born in 1835, arrived in Sydney at the age of ten, and came 
to Queensland a dozen years later, working as a manager on a series of pastoral stations, including Jimbour. At the age of 39 he published The two visions; or the contrast - 'my first attempt at anything continuous', as he calls it. ${ }^{12}$ It is a long meditation, alternately chatty and abstruse, on the Australian environment, full of literary allusions, scientific (mainly botanical) jargon, informative footnotes, and a disconcerting tendency to playfulness, punning and self-parody. Here he describes a garden:

Halfway adown an undulating slope,

That towards us turns with equable incline,

A lovely garden settles in the midst

Its roofed rorifluent recesses ramped

By native evergreens with clustered flowers.

'Rorifluent' is in Johnson's Dictionary: it means 'flowing with dew', but he glosses the line in which it occurs, clearly ironically, as 'intended for perusal by the writers of some of the articles in "London Society". ${ }^{13}$

Mayne was a disciple of the Irish national bard, Thomas Moore, to whose memory he dedicates it, and whom he quotes frequently. But he was also an admirer of Matthew Arnold's lectures on the study of Celtic literature (1867), which he quotes in his Preface on the (partly scientific) task of the modern poet - 'to interpret human life afresh, and to supply a new spiritual basis for it'. ${ }^{14}$ Arnold's lectures defined the Teutonic (or Saxon) and Celtic temperaments as polar opposites: the former masculine, rational, energetic and 'heavy'; the latter feminine, intuitive, ineffectual and 'light'. Like a surprising number of Irish poets and intellectuals of the period, Mayne embraced the demeaning stereotype contained in Arnold's ethnology, and used it to establish a certain kind of persona in his poem:

The task performed I could not shun -

Say, Critic, is the laurel won?

Don't think I so presumptuous be

As to expect a full-grown tree

Is requisite from which to cull

A wreath to decorate my skull.

If you can grant the smallest meed

'Twill be encouragement indeed! 15

Following Mayne, there were three more male Irish migrant-poets, all born a generation later, in the 1860s: Cornelius Moynihan, Henry Barkley and Thomas Watters Boyce. Cornelius (known as 'Con') Moynihan, the oldest of them, was born near Killarney in County Kerry where, as a child of five, he remembered seeing redcoated dragoons marching through the glens in pursuit of Fenian rebels in $1867 . \mathrm{He}$ arrived in Australia with his family as a seven-year-old in 1869. He grew up in the Brisbane suburb of Ascot, found a job in the Queensland Parliamentary Library and by the age of twenty had risen to assistant librarian at the Parliamentary Library, a post he held until his death 32 years later.

Moynihan began writing early, publishing his first book of verse under the pseudonym (also used by Oscar Wilde) of 'Vivian' at the age of eighteen, and his last, a jingoistic effort called The German Armageddon: Ballads of the Kaiser's war, in 1915, a few months after Gallipoli and a few months before his own 
death, aged 54. In between, he published The Bunyip of Wendouree (1910), a volume containing a number of 'occasional' and memorial poems, some narrative and reflective verses on Aboriginal themes and the title poem of the volume, a whimsical tall tale in which Rob Roy M'Gregor, a Scottish Highland chieftain transported for poaching, meets a Gaelic-speaking bunyip who first deposits him with an Aboriginal tribe for forty-five years, then gets him to Ballarat just in time for the Eureka Stockade. ${ }^{16}$

This peculiar poem provides starting points, oddly enough, for Moynihan's two most ambitious productions, The feast of the bunya and 'Eureka'. The first is subtitled 'An Aboriginal ballad', and it is a narrative account in about a hundred eight-line stanzas, of the three-yearly pilgrimage of the local tribes to Mobolon, the highest point of the Bunya Mountains, there to feast on the bunya nuts. It includes, as digressions, several stories of the contact between white and black, including such events as the notorious massacre of about sixty Aborigines, poisoned with strychnine-laced damper on the Kilcoy run in 1842, and the Hornet Bank murder of the Fraser family in 1857. Counterpointing these atrocities is the steady and peaceful progress of the tribes to Mobolon in the Bunya Mountains, offering a brief respite to their grateful prey:

Boonara's hills are silent,

Nanango's valley lone;

In all the spacious marshland

No boomerang is thrown.

The wild fowl haunt Cooloola,

With fish the rivers teem;

But now, no torches flash by night

Along Barambah's stream.

The dingo, unmolested,

May slake his thirst at noon;

Unharmed, the swan at midday

Floats on the broad lagoon;

Round the salt spring at nightfall,

The timid curlews shriek;

Unhurt, the duck-billed platypus

Tunnels along the creek. ${ }^{17}$

Moynihan's closest model for The feast of the bunya is Longfellow's immensely popular Song of Hiawatha - he was a great admirer of Longfellow, and wrote a memorial poem in his honour - but it is a remarkably original and finished achievement in its own right. In hindsight, we can hardly fail to be amused by its 'Jindyworobak-isms', but the diction remains relatively uncluttered, and Moynihan's honest and thoughtful attempt to integrate the recent histories of Aboriginal and European populations on a single plane may be a more convincing representation of that 'fusion of cultures' that Rex Ingamells sought than he and the other Jindyworobak poets achieved forty years later. ${ }^{18}$ Contemporary critics and reviewers of the Feast were generally favourable, though some objected to the quantity of Aboriginal lore and language included in the notes. In any case, the poem gained 
considerable public prominence when it was presented to the Duke and Duchess of York on the occasion of their Federation visit to Brisbane in $1901 .{ }^{19}$

Their Royal Highnesses would perhaps have been less pleased to receive a presentation copy of Moynihan's other major work, 'Eureka', even though it is more than twice the length of The feast of the bunya. One hardly needed to travel to the other side of the globe, after all, to hear stories about Irish rebels! Partly because Peter Lalor himself was Irish (and the brother of one of the Young Ireland ringleaders, James Fintan Lalor), Eureka was a favourite topic with Irish poets and readers in Australia in the late nineteenth century, and Moynihan's 2,000-line effort is one of the most impressive treatments of it. It is unfortunate that he was not able to publish it - the Melbourne reader for Ward Lock \& Co. was impressed by its narrative energy and technical virtuosity, but regarded the subject as 'too parochial' to be of interest to his firm, a judgement that understandably infuriated Moynihan and called forth an eloquently aggrieved letter. ${ }^{20}$

Moynihan often lamented, as his female antecedents had done, about the lack of a vigorous poetic culture in Queensland:

Alas, we have no Byron now!

No minstrel touch to wake the lyre!

Do these degenerate times allow

Of deeds that should the bard inspire?

Taken as a whole, his career as a poet successfully explores a multiplicity of roles available to the poet within what might be called the 'Irish paradigm' - exile, lover, social prophet, heroic bard - if also a nagging suspicion that these roles and functions were not authentically available in Queensland.

Henry Barkley, born in County Antrim in 1865, seems to have been troubled by no such paradoxes. He arrived in Queensland at the age of 22, was employed by the Queensland Railways until 1902, then ran a series of grocery businesses for twenty years in Dalby and later in the suburb of Coorparoo, where he died in 1932. His sole volume of poems, Lyrics from the Line, was published by the Railway Times Office at Ipswich in 1898. Barkley, whose pen-name was 'The Goth', was a staunch unionist - very much the poet of the Common Man. He makes this clear in two ways. First, he contrasts his poetic aims with those of 'learned' poets - for example, in his poem 'Learning' (very probably with Mayne and Moynihan in mind):

No! I have no wish to tamper with words forty letters long;

Placing them in false positions - giving half their meanings wrong -

Making them seem sheeted spectres, standing ever in the way;

Or like wrecker's midnight beacons, with their false, alluring ray.

Why! big words and lofty phrases are like noisy bladders cracked;

They are thunder without shower; force without the least effect.

Strength must in the thought be centred; it is never in the words;

Flimsy thoughts with adverbs blended are but whey without the curds.

Why should I use Latin phrases when the English tongue I speak?

Why should I for ever borrow from the German, French and Greek?

Why should I display my folly, and my lack of common sense

Just to 'gammon' I'm a scholar - learned in arts of vain pretence. ${ }^{21}$ 
Second, class and Celticism seem to have been more important to him than Irishness. So, for example, a eulogy on James Kelly — a Scottish worker-poet — places him in the company of Robert Burns and Walter Scott.

Barkley's interest is in the political issues of contemporary Queensland, and also Ireland. In 'A Retrospect of the Year 1893', he gives us a wonderful digest of the events that excited an intelligent and committed socialist in that remarkable year, 120 years ago:

This year beheld the sons of toil, with hearts determined bold,

Smite on electoral battle-field the worshippers of gold;-

There Labour dashed aside her chains, and threw her yoke away

And fifteen of her noble sons are MLAs today.

This year has looked on William Lane, with purpose fix'd and true,

Sail far away to distant lands across the ocean blue; -

There to up-build a social state, [where] justice shall be queen,

And where the sweater's cunning face, nor greed shall e'er be seen.

This year beheld the prison doors, on St Helena's isle,

Ope wide and let the 'Union Men' come forth from durance vile.

This year looked on the floods that swept Victoria Bridge away,

And that decked many a ruined home with wreaths of foamy spray.

This year has seen the franchise used by women wise and well;

Thus sounding louder than before oppression's funeral knell.

This year beheld the World's great fair, and heard the Home Rule Bill;

And saw reforms spring up and grow on every Council Hill. ${ }^{22}$

In Barkley's volume, the usually obsequious poetic address to the Queen becomes instead an indictment of privilege and power: 'Now, great Queen of England, tell us, why is poverty a crime? / Why is Wealth the King of Nations, and the god of every clime?'23 But the railwayman-cum-poet is also aware of the weaknesses of working-class men. 'The Wreck' describes a rail disaster caused by a drunken driver, and counsels:

... drivers, when you drive at night,

Tho' tempests rage, and bleak winds bite,

Touch not the drink that dulls the brain,

And crowds the mind with fancies vain;

Let not foul spirits be your guide,

Nor with you on the engines ride. ${ }^{24}$

The third poet of the group is Thomas Watters Boyce, who published four volumes of poetry between 1928 and $1930 .{ }^{25}$ Born in Belfast in 1866, he came to Queensland at the age of eighteen and worked for most of his life in the timber business and the Lands Department. He died in 1950 at the age of 84 . Although on the whole he is a less interesting poet than the others discussed here, he wrote a couple of rollicking bush narratives that are quite long and use a surprising variety of metrical forms (a feature on which the original press reviewers commented approvingly). He also writes about local landscapes and some very tedious theosophical poems. What he doesn't write about - ever — is Ireland: the most important thing about Belfast for Tom Boyce is that he left it! 
After Boyce, it is downhill all the way as far as quality is concerned. James Sweeney was born in Galway in 1875 and arrived in Queensland in 1930 at the age of 55 . We have been unable to ascertain whether he had previously lived elsewhere in Australia - he may have lived in Sydney — but in any case he returned to Ireland in 1945. During his fifteen-year sojourn in Queensland, he published no fewer than five books of verse, but there is far less to this oeuvre than meets the eye, for they were of pamphlet size, and the first four are successive editions of the one small collection.

These books are of interest because Sweeney maintains such an unproblematic relationship between his Irish and Australian identities. There is no agonising, like Eva O'Doherty's, about unpoetical Queensland skies; no uncertainty, like Con Moynihan's, about the role of the Irish poet in Queensland. Sweeney simply writes about Ireland and Australia, with equal enthusiasm, often on alternate pages. This approach appealed to the Catholic press. The Catholic Leader and the Freeman's Journal both recommended the volume warmly as 'a source of inspiration and pleasure'. The Leader's reviewer says: 'His love of Ireland appears in "The exile", "Beauties of Galway", "Clew Bay" and others, while Australia is celebrated in "My native land", "Ode to Australia", and "Brisbane rose".' The reviewer also commends his love of nature in 'Get back to the bush':

Get out in the bush where your chest will expand

And fill up your lungs with fresh air, oh, it's grand!

Get out in the bush, see the slick kangaroo,

The dingo, opossum, black and white cockatoo.

Get out in the bush, and hear nature sweet songed

Where you grow strong and hearty and life is prolonged.

Get out in the bush, far from worry and strife;

Don't ever return, stay out there all your life. ${ }^{26}$

Clearly, Sweeney's poetry was meeting the needs and tastes of a certain audience: Catholic and culturally unsophisticated. It was a very different one from the cultivated audiences that both Mayne and Moynihan addressed, different again from the working-class socialists Barkley was addressing, and different yet again from the middle-class nationalists Boyce had in his sights. 'Eva' and 'Thomasine' had struggled to find a voice, but Sweeney's easy assimilation was echoed by several women writers who were more at ease with the cultural and religious dimensions of their heritage than with politics - either Irish or Australian. Nostalgia for Ireland is a key theme in the work of Irish-born women, and is most typically expressed through evoking memories of landscapes, people and culture.

Anglo-Irish Presbyterian poet Sarah Patterson captures the nostalgia, with its inevitable undercurrent of melancholy, in 'My country':

Oh, Erin, my country! Green star of all ages,

Thy bards have sung of thee in undying songs;

Thy patriots have opened sad darkling pages,

And read to the world of thy unredressed wrongs. ${ }^{27}$

Born in Belfast in 1841, Patterson arrived in Gympie in 1868 with her husband, Lieutenant-Colonel George Patterson. As indicated by the title of her only volume of poetry - Glorious Australia: The land of my adoption (published in 1906) - 
she was generally more concerned with extolling the wonders of the new land than dwelling on the 'unredressed wrongs' she had left behind.

Paradoxically, it was the Queensland-born novelist Rosa Praed, also of AngloIrish ancestry, who was most conscious of parallels between Ireland and Australia. Her father, Thomas Lodge Murray-Prior, was the descendant of a family that had been granted estates in Rathdowney in the seventeenth century and her mother, Matilda Harpur, was born near Cookstown in County Tyrone. Rosa Murray-Prior was born at Bromelton on the Logan River in 1851, and left Queensland for London in 1876, after her marriage to Arthur Campbell-Praed. In England, she became one of the best-selling novelists of her day. Of particular interest in the present context is her friendship and literary collaboration with Justin McCarthy, the Irish nationalist leader, whom she accompanied to the United States in 1886 to shore up American support for a constitutional solution to the Irish question. Curiously enough, Justin McCarthy and Dr Kevin Izod O'Doherty both held seats for the Irish National Party in the House of Commons in 1886, when the Home Rule Bill was introduced. ${ }^{28}$

In her novel, Lady Bridget in the Never-Never Land (1915), Praed explicitly likens British oppression of Ireland to the dispossession of Aborigines in Australia. When pastoralist Colin McKeith describes his shooting of King Mograbar, the Irish aristocrat Lady Bridget O'Hara retorts: 'How cruelly unjust. It was his country you were stealing.' She continues: 'I don't admire your glorious British record, I think it's nothing but a record of robbery, murder and cruelty, beginning with Ireland and ending with South Africa. ${ }^{29}$ This dramatic accusation, which appeared in print just a year before the Easter Rising in Dublin, probably struck more of a chord with Praed's large British audience than with Queenslanders, who were remarkably lacking in enthusiasm for Irish nationalism, and even less inclined to regard themselves as usurpers.

Many of Rosa Praed's other novels introduce Irish characters and themes, but none more dramatically than Outlaw and lawmaker (1893). ${ }^{30}$ The title alludes to the double life of Morres Blake, a Fenian who is the disgraced younger brother of the Irish aristocrat Lord Coola. In 'Leichardt's Land' (Queensland), Blake is elected to parliament as a Radical and becomes a capable and responsible Colonial Secretary, but he also leads a secret life as the infamous bushranger, Captain Moonlight. The motives of the 'kingly' Blake are pure: 'I have robbed, not for greed of gain, but for Ireland. ${ }^{31}$ However, his accomplices, Dominic Trant and Sam Shehan, taint the nationalist project by stealing for personal gain. Blake's criminal identity is eventually exposed, and the police close in on his secret hideaway of Baròlin Rock (Mt Maroon in the McPherson Range) just as news is received that Blake's brother and nephews have died. The Irish patriot - now Lord Coola - does the only honourable thing and throws himself off the precipice. ${ }^{32}$

Susan Sheridan argues that: "The remarkable popularity of "Irish aristocrats" in [Australian fiction] suggests that this was a way of claiming Irish origins without risking the "convict taint" or the "racial" inferiority often attributed to the Irish in Australia. ${ }^{33}$ Praed, however, did have convict associations in mind in Outlaw and lawmaker: she modelled Morres Blake in part on the Irish Fenian, John Boyle O'Reilly, who was transported to Western Australia and freed by American whalers in $1869 .{ }^{34}$ She may have looked closer to home too, modelling Blake in part on the parliamentarian and former convict Dr Kevin Izod O'Doherty. Praed appears to be 
pushing her Australian readers, albeit gently, towards a rereading of the causes of Irish criminality and redefinition of the Irish character.

While the overtly political dimension of Irishness in Praed's work found few echoes among writers living in Queensland, her fascination with the glamour of Irishness had more resonance. Local writers turned their attention instead to remaking an 'old tradition's magic' in their new land, by conflating Irish ideals of family, religion and beauty with Queensland landscapes and people, or by drawing on Celtic myth and legend. This approach, too, had the effect of uncoupling Irishness from the convict taint and notions of racial inferiority. In the early twentieth century, 'Faerie' - or the world of the Celtic twilight - functioned for many poets (whether of Irish descent or not) as a vehicle for escaping the constraints of patriotic or bush poetry, and projecting women writers in particular towards a more cosmopolitan agenda.

Rockhampton-born Ernestine Hemmings (better known as Ernestine Hill, author of My love must wait) was a schoolgirl at All Hallows' School in Brisbane when her earliest poems were published in the children's page of the Catholic Advocate in 1916. Later that year, the Hibernian Newspaper Co. issued a volume entitled Peter Pan land and other poems, with a preface by Archbishop Duhig. In the title poem, the seventeen-year-old convent girl evokes the passing of Neverland - innocence - in a disturbingly unchildlike way:

Have you ever lived in the Neverland, the Island of Peter Pan, Where nobody grown up ever goes, 'cause nobody grown up can?

$\cdots$

There's only just laughter, and love, and fun, in Peter Pan's domain.

But the island is always drifting, it glides to the river-bar,

And it's funny you never notice till you find that it's gone too far;

You have to be oh! so careful if you want to make it stay, -

It slips so fast down the Stream of Now to the Ocean of Yesterday. ${ }^{35}$

The precociously adult sensibility in this piece foreshadows the bohemian life on which the young poet would shortly embark in Sydney. Meaghan Morris has pointed to the self-consciously Irish and Catholic modernism of the young poet's Brisbane milieu. ${ }^{36}$ In Hemmings's early work, this modernism manifests itself in the universalising tendency of faerie subject-matter, which eschews a sense of place: only two of her early works - 'The Convent Walls' and 'The Song of the Curlew' allude to the poet's location in Queensland, and none specifically to anything unequivocally Irish.

Queensland's two best-known 'Irish' poets, the Queensland-born Margaret Curran and the Irish-born Alice Guerin Crist, pursue a much more grounded literary project, giving expression to what Professor J. J. Stable designated in speaking of Curran as 'the true Irish temperament'. ${ }^{37}$ Both poets depict Queensland as a home of Irishness, thus overcoming the sense of cultural rupture evident in the work of Eva Mary O'Doherty and Mrs Hope Connolly. Born Margaret Toohey at Colinton Head Station near Esk in 1877, Curran elaborates an Irish - and Catholic identity through her Irish patriotic poems, comic Irish dialect poems such as 'Ae Nighte', religious devotional works and verse for children. She presents the Irish struggle from the perspective of a mother or lover, focusing on personal loss rather than political gain. 'They say she walks abroad again' is the lament of a mother 
broken by the loss of her fifth son to the nationalist cause: she pleads ' $\mathrm{O}$, Kathaleen ni Houlihan, walk no more this sad land!' Likewise, Curran invokes Parnell as 'Son of the curse': 'tis very well you died / ... you might have lived to chide / The woman of your heart - for your lost dreams. ${ }^{38}$ Curran's local popularity was soon eclipsed, however, by the meteoric career of her Irish-born friend and fellow Toowoomba resident Alice Guerin Crist.

Alice Guerin Crist was born at Clare Castle, near Ennis, County Clare in 1876, and migrated to Queensland at the age of two. From 1902 until her death in 1941, she lived in Toowoomba. She published little until she was in her fifties, but rapidly became extremely popular with Irish Catholic audiences in Queensland and beyond. ${ }^{39}$ Often likened to John O'Brien, the Irish poet of New South Wales, Crist drew on Celtic faerie themes, the Australian bush and the Irish character in the poems collected in her first volume, When Rody came to Ironbark (1928). ${ }^{40}$ Whereas the work of Connolly and O'Doherty arose out of a commitment to a cause, and is indebted to the Irish high cultural tradition, Crist's poetry uses folk idioms and dialects, and avoids politics. Her keen ear for the Irish idiom and her fluency with ballad forms - perhaps the qualities for which Mary Gilmore dubbed her 'Queensland's singer of graceful songs' ${ }^{41}$ - are exemplified in the opening to one of her finest poems, 'Himself', spoken poignantly by an Irish widow:

Last night, when I was listenin'

Alone, to wind and rain,

He took the chair beside me,

Himself — come home again. ${ }^{42}$

A poem simply entitled 'O'Shea' 43 celebrates the heroism of an unassuming Irish railway ganger who sacrifices his own life to save that of a child in a train crash, while 'Homesick' vents nostalgia for the Irish homeland:

Ah! no, I'm not repinin',

And I love this wide new land,

And I'm proud to see the childer

Growin' prosperous and grand,

But roots strike deep in Irish soil,

Old memories are sweet,

And to-night my heart is yearnin' for the cabin I was born in,

And I smell the reek of turf-smoke driftin' up the city streets. ${ }^{44}$

Crist's best-known poem, 'When Rody came to Ironbark', opens with a portrait of a young Queensland Irish blade:

When Rody came to Ironbark, there spread a hectic glow

Around the little township - a dozen years ago,

And the townsfolk were divided, twixt laughter and dismay,

At the roysterin' ways of Rody - the madcap tricks he'd play.

...

When Rody came to Ironbark, 'twas fun to watch the girls,

Such sorting out of frills and frocks, such pinning up of curls ...

All the girls pine and sigh for Rody save little Nora Shanahan, who prays that he will choose her and 'Heaven always answers when souls like Nora's pray':

So, Rody comes to Ironbark, proud, prosperous and neat - 
A dozen hats are lifted as he drives along the street -

And Nora sits beside him, all calm and matronly:

There are four small folk behind them, and one on Nora's knee

Though the wild lads muse regretfully the good old days upon, And all the township gossips say 'Another good man gone!'45

These depictions of Irish life in the new land, which have no pretensions to learning or higher literary traditions, evoke the bitter-sweetness of the process of adjustment to a new land. They capture both nostalgia for the old culture and the vitality and potential of the new country, where children grow 'prosperous and grand'.

In response to demand from her Catholic readers and editors, Crist's later poems are more explicitly Catholic in their subject-matter. Her second volume of verse, Eucharist lilies (1928), written for the Eucharistic Conference in Sydney, contains devotional works and celebrations of Australian Catholic history. ${ }^{46}$ She also published a novel for adolescents, entitled 'Go it! Brothers' ${ }^{47}$ Dedicated to the Christian Brothers of Australia, the novel is set in a Queensland country town recognisable as Toowoomba, among boys at St Mary's Christian Brothers School. The cry of 'Go It! Brothers' during football matches against the Grammar School punctuates the novel. In a Queensland very much divided along sectarian lines, Crist was less likely than other Irish writers to attract a wide readership.

While Crist met the needs and tastes of a conservative Irish Catholic readership, Mabel Forrest - a Protestant whose paternal grandmother was from Galway used Irishness as one strand of an urban, cosmopolitan, secular, female aesthetic that made her one of the most popular women writers in Australia in the 1920s. Her poetry draws heavily on faerie subject-matter, which explored spiritualist or psychic dimensions without sectarian associations. Her novels include a number of Irish characters who have supernatural insight, and explore themes that might now be termed 'New Age'. White witches (1929) is a novel about Irish Maeve and her daughter Synfye, the 'white witches' ${ }^{\text {' }}$ of the title; Synfye marries Liam M'Pheris, an Irish pig farmer who plays the flute. The fey Irish Maloney family had earlier provided a faerie sub-plot in Gaming gods (1926). ${ }^{49}$

Forrest's most famous novel, The wild moth (1924), which was filmed by Charles Chauvel in 1926 as The moth of Moonbi, also has an intriguing 'Irish' twist to its plot. The skin colouring of Dell, the protagonist, hints at the possibility of racial impurity, and the mystery of her paternity has to be resolved before she can marry. The discovery that Dell is the product of her mother's illicit liaison with an Irish artist is sufficient to reinstate her to all the privileges of whiteness. ${ }^{50} \mathrm{In}$ the context of the 1920s, the novel is 'progressive' in its redemption of Irishness and illegitimacy: the Aboriginal, however, remained the disturbing Other, who through miscegenation might infiltrate white society. Anxieties about race manifest themselves in odd ways. Forrest wrote a short story entitled 'The little black man', in which a black Gaelic goblin 'who does not like to talk about the White Australia policy' has his love for a pink waterlily sanctioned by her kiss ${ }^{51}$ - Cornelius Moynihan's time-travelling, Gaelic-speaking bunyip redivivus!

Some of Queensland's Irish immigrant poets, then, brought with them a sense of the social functions and cultural status of the poet. Others seem to have abandoned them - or never adopted them in the first place — and suited their aspirations 
to the simpler, more immediate demands of the environment in which they found themselves. The Queensland Irish were more integrated, and less active in the nationalist cause, than elsewhere in Australia, and this assimilative, depoliticising tendency is also evident in the work of Queensland writers of Irish birth or descent. Irishness manifests itself in the writing of second- and third-generation descendants of Irish immigrants - especially women - principally as a romanticised ideal. The glamour of Irishness redefines the taint of Irish racial inferiority and criminality, and Irish faerie mythology becomes a key component of a modernist literary agenda that is simultaneously both secular and psychic. The remaking of 'an old tradition's magic' by writers of Irish birth or descent is a distinctive strand in Queensland writing from Separation to the mid-twentieth century.

\section{Endnotes}

1 J. H. Hornibrook, Bibliography of Queensland verse with biographical notes (Brisbane: Government Printer, 1953).

2 Eva O'Doherty, 'My voice of song', Poems by 'Eva' of the 'Nation' (Dublin: M.H. Gill, 1909), pp. 20-1.

3 H. A. Kellow, Queensland poets (London: Harrap, 1930), pp. 107-8; Mrs Hope Connolly, Thomasine's poems: wild flowers from the wayside (Dublin: James Duffy and Sons, [1883]).

4 Mrs Hope Connolly, 'A remonstrance: To "Eva”', in Thomasine's poems, pp. 21-3.

5 Mrs Hope Connolly, 'Mater dolorosa', in Thomasine's poems, p. 111.

6 Mrs Hope Connolly, 'The contrast: II', in Thomasine's poems, p. 120.

7 Including 'The boomerang,' "'L. L."' (on Ludwig Leichhardt) and 'Storm in the bush'.

8 Eva O'Doherty, 'Queensland', in Poems, p. 92.

9 Eva O'Doherty, 'Queensland', in Poems, pp. 92-3.

10 Ross and Heather Patrick, Exiles undaunted: the Irish rebels Kevin and Eva O'Doherty (St Lucia: University of Queensland Press, 1989), p. 174. See also Patrick Buckridge, 'Two Irish poets in colonial Brisbane: Eva O'Doherty and Cornelius Moynihan', in Jonathan Wooding (ed.), Old myths and new lights (Brisbane: Queensland Irish Association, 1991), p. 22.

11 Mary Egan Mulry, 'My dream', in Glorious Australia: the land of my adoption (Brisbane: Crofton Print., [ca 1926]), n.p.

12 Robert West Mayne, The two visions, or, the contrast: an Australian story (Sydney: F. Cunninghame \& Co., 1874), p. [i].

13 Mayne, The two visions, pp. 37-8, $38 \mathrm{n}$.

14 Mayne, The two visions, p. [i].

15 Mayne, The two visions, Epilogue, p. 60.

16 The Bunyip of Wendouree and other poems by Cornelius Moynihan, Brisbane, 1910, draft copy in Fryer Memorial Library, University of Queensland.

17 Cornelius Moynihan, The feast of the bunya: an Aboriginal ballad (Brisbane: Gordon and Gotch, 1910), pp. 54-5.

18 See Rex Ingamells, 'Conditional culture' [1938], in John Barnes (ed.), The writer in Australia: a collection of literary documents, 1856-1964 (Melbourne: Oxford University Press, 1969), pp. 245-59. 
19 'Another presentation book', The Brisbane Courier, 14 June 1901, 6. See also cutting, n.d., from Brisbane Telegraph in The Bunyip of Wendouree, Fryer Library.

20 A manuscript copy of the poem exists in the Queensland Parliamentary Library, together with the correspondence between Moynihan and Ward Lock \& Co.

21 'The Goth' [Henry Barkley], 'Learning' in Lyrics from the line (Ipswich: Railway Times Office, 1898), p. 31.

22 Henry Barkley, 'Retrospect of the year 1893', in Lyrics, p. 24.

23 Henry Barkley, 'Address to her Majesty, the Queen', in Lyrics, p. 55.

24 Henry Barkley, 'The Wreck', in Lyrics, p. 35.

25 The four volumes by Thomas Watters Boyce are Evening reveries (Brisbane Exchange Printing Co., 1928); The reply (Brisbane Exchange Printing Co., 1928); Whispering echoes (Brisbane Exchange Printing Co., 1928); and The battle of life and other verse (London: Stockwell, 1930).

26 James Sweeney, 'Get out in the bush', in Original verse (Brisbane: Read Press, 1935), n.p.

27 Sarah A. Patterson, 'My country', in A garland of thought (Melbourne: George Robertson and Co., 1906), p. 101. For work in a similar vein, see Margaret A. Cope, 'Newcastle, County Down', in Meditation in verse (Brisbane: Carter-Watson, 1929), pp. 103-4.

28 See Patricia Clarke, 'Rosa Praed's Irish connections', Australian Journal of Irish Studies 1 (2001), 118-25; Patricia Clarke, Rosa Rosa! A life of Rosa Praed, spiritualist and novelist (Melbourne: Melbourne University Press, 1999); and Kay Ferres, 'Shrouded histories: Rosa Praed and liberal politics', Australian Literary Studies 21, 1 (2003), 32-42. O'Doherty and Praed almost certainly met, perhaps even in Brisbane where Kevin O'Doherty and Thomas Lodge Murray-Prior were both Members of Parliament, or in London, where Rosa Praed assiduously frequented the debates on Home Rule (see Ferres, 'Shrouded histories').

29 Rosa Praed (Mrs Campbell Praed), Lady Bridget in the Never-Never Land (London: Pandora, 1987 [1915]), p. 47.

30 Rosa Praed (Mrs Campbell Praed), Outlaw and lawmaker (London: Pandora, 1987 [1893]).

31 Praed, Outlaw and lawmaker, p. 278.

32 Praed, Outlaw and lawmaker, p. 306.

33 Susan Sheridan, Along the faultlines: sex, race and nation in Australian women's writing, 1880s-1930s (Sydney: Allen \& Unwin, 1995), p. 54.

34 Clarke, 'Rosa Praed's Irish connections', 123. Praed had met and been charmed by Boyle in Boston in 1886.

35 Ernestine Hemmings [later Hill], Peter Pan land and other poems (Brisbane: Hibernian Newspapers, 1916), pp. 15-16. In Sydney, Hemming had a relationship with Robert Clyde Packer, then manager of Smith's Weekly; her son, Robert, born in 1924, is thought to be his child. At this time, Hemmings assumed the surname Hill, but she never married.

36 Meaghan Morris, 'The fairies of the day: Ernestine Hill's education in Brisbane', unpublished paper presented at the Centre for Advanced Studies in the Humanities, Griffith University, 21 May 1999. In this paper, Morris also discussed the 'knowingness' of Hemmings's early poems.

37 J. J. Stable, foreword to Margaret Curran, The wind blows high and low and other verses (Brisbane: Carter-Watson, [1928]), p. [7]. On Curran and Crist, and specifically their leading roles in the Toowoomba Ladies' Literary Society, see Christopher Lee, 'A society of country women and the functions of literary property', Journal of Australian Studies 52 (1997), pp. 138-47. 
38 Curran, The Wind, pp. 25, 30.

39 Dimity Dornan, Alice with eyes a-shine: seedlings of an Irish-Australian childhood (Brisbane: Church Archivists' Press, 1998), p. 142. Crist began writing for the Catholic Advocate on 10 June 1927, and produced 95 poems, short stories and serial instalments selected in the first six months.

40 Alice Guerin Crist, When Rody came to Ironbark and other verses (Sydney: Cornstalk 1927). The work of John O'Brien is advertised on the back cover of When Rody came to Ironbark.

41 Dornan, Alice, p. 155.

42 Alice Guerin Crist, 'Himself', in When Rody, p. 21.

43 Alice Guerin Crist, 'O'Shea', in When Rody, pp. 47-49.

44 Alice Guerin Crist, 'Homesick', in When Rody, p. 63.

45 Alice Guerin Crist, 'When Rody came to Ironbark', in When Rody, pp. 35-7.

46 Alice Guerin Crist, Eucharist lilies (Sydney: Pellegrini, [1928]).

47 Alice Guerin Crist, 'Go it! Brothers' (Sydney: Pellegrini, 1932).

48 Mabel Forrest, White witches (London: Hutchinson, [1929]), pp. 247-8.

49 Mabel Forrest, Gaming gods: a novel (London: Hutchinson, [1926]).

50 Mabel Forrest, The wild moth (London: Cassell, 1927 [1924]).

51 Mabel Forrest, 'The little black man', in The green harper (Brisbane: Gordon and Gotch, 1915), p. 20. 